\title{
Ionic Conductance(s) in Response to Post-junctional Potentials
}

\author{
Sang Don Koh ${ }^{1}$ and Poong-Lyul Rhee ${ }^{2 *}$ \\ ${ }^{1}$ Department of Physiology and Cell Biology, University of Nevada, School of Medicine, Reno, NV, USA; and ${ }^{2}$ Division of Gastroenterology, \\ Department of Medicine, Sungkyunkwan University School of Medicine, Samsung Medical Center, Seoul, Korea
}

The gastrointestinal motility is regulated by extrinsic and intrinsic neural regulation. Intrinsic neural pathways are controlled by sensory input, inter-neuronal relay and motor output. Enteric motor neurons release many transmitters which affect post-junctional responses. Post-junctional responses can be excitatory and inhibitory depending on neurotransmitters. Excitatory neurotransmitters induce depolarization and contraction. In contrast, inhibitory neurotransmitters hyperpolarize and relaxe the gastrointestinal smooth muscle. Smooth muscle syncytium is composed of smooth muscle cells, interstitial cells of Cajal and platelet-derived growth factor receptor $\alpha$-positive (PDGFR $\alpha^{+}$) cells (SIP syncytium). Specific expression of receptors and ion channels in these cells can be affected by neurotransmitters. In recent years, molecular reporter expression techniques are able to study the properties of ion channels and receptors in isolated specialized cells. In this review, we will discuss the mechanisms of ion channels to interpret the post-junctional responses in the gastrointestinal smooth muscles.

(J Neurogastroenterol Motil 2013;19:426-432)

Key Words

Gastrointestinal motility; Ionic conductance; Post-junctional potentials

\section{Introduction}

Stimulation of enteric motor neuron releases many neurotransmitters and neuropeptides. To evoke post-junctional electrical responses, many ion channels in smooth muscle cells (SMCs) or specialized cells (e.g., interstitial cells of Cajal [ICC] and platelet-derived growth factor receptor $\alpha$-positive [PDGFR $\left.\alpha^{+}\right]$cells) can be activated. ${ }^{1,2}$ Post-junctional responses can be categorized by 2 components: excitatory junction potentials (EJPs) and inhibitory junction potentials (IJPs). EJPs are mediated by ace- tylcholine (ACh) and neurokinins (NKs). Muscarinic receptors respond to $\mathrm{ACh}$ released from cholinergic neurons. Muscarinic receptors (M2 and M3) are expressed in the gastrointestinal (GI) smooth muscle. Three neurokinins (NKs) are substance P, neurokinin A and neurokinin B. These NKs are mediated by activation of neurokinin receptors (NK1-3). IJPs are mediated by purines, nitric oxide (NO), vasoactive intestinal peptide (VIP) and pituitary adenylate cyclase-activating peptide (PACAP). Purines bind to purinergic receptors, in particular $\mathrm{P} 2 \mathrm{Y}$ receptors. NO directly activates soluble guanylate cyclase. VIP and PACAP act through VPAC1 and VPAC2. Besides NO, most

Received: August 13, 2013 Revised: August 28, 2013 Accepted: August 30, 2013

(c) This is an Open Access article distributed under the terms of the Creative Commons Attribution Non-Commercial License (http://creativecommons. org/licenses/by-nc/3.0) which permits unrestricted non-commercial use, distribution, and reproduction in any medium, provided the original work is properly cited.

*Correspondence: Poong-Lyul Rhee, MD

Division of Gastroenterology, Department of Medicine, Sungkyunkwan University School of Medicine, Samsung Medical Center, 81, Irwon-ro, Gangnam-gu, Seoul 135-710, Korea

Financial support: None.

Tel: +82-2-3410-3409, Fax: +82-2-3410-6983, E-mail: plrhee@skku.edu

Conflicts of interest: None. 
neurotransmitters or neuropeptides are coupled to G-proteins. These $G$ protein coupled receptors have a unique relationship with specific G-proteins and thus activate ion channels in unique ways. Recently the post-junctional responses are focused on the roles of intermediary cells between neurons and SMCs. These cells are ICC and PDGFR $\alpha^{+}$cells. ${ }^{1,2}$ Thus, in this review, we will discuss the ion channel candidates with cell-specific roles which can be modulated by neurotransmitters or neuropeptides.

\section{Cholinergic Excitatory Response}

$\mathrm{ACh}$ is the major excitatory neurotransmitter ${ }^{3}$ and plays a primary role in increasing the contractile force in GI motility. Cholinergic excitatory responses are mediated by 2 types of muscarinic receptors (M2 and M3). ${ }^{4} \mathrm{M} 2$ receptors are highly expressed in SMC. M2 receptors act via $\mathrm{G}_{\mathrm{i} / \mathrm{o}}$ proteins which decrease the production of cAMP. ICC expresses mainly M3 receptors. ${ }^{5,6} \mathrm{M} 3$ receptors are coupled to $\mathrm{G}_{\mathrm{q} / 11}$ which activates phospholipase C (PLC) and its downstream signaling pathways. Activation of PLC hydrolyzes phosphatidylinositol 4,5-bisphosphate (PIP2) into diacylglycerol and inositol-1,3,4-triphosphate (Ins-1,4,5-IP $\left.)_{3}\right)^{7,8}$ The PLC blocker U-73122 and the anti- $\mathrm{G}_{\mathrm{q} / 11}$ antibody inhibit muscarinic activation of non-selective cation currents $\left(\mathrm{m} I_{\mathrm{CAT}}\right)$ in murine gastric myocytes. ${ }^{9}$ The effects of inhibiting PLC on $\mathrm{m} I_{\mathrm{CAT}}$ were found to be independent of triphosphage $\left(\mathrm{IP}_{3}\right)$, diacylglycerol or $\mathrm{Ca}^{2+}$ store depletion in guinea pig ileal myocytes ${ }^{10}$ and in murine gastric myocytes. ${ }^{11}$ One interpretation of this finding is that activation of PLC is coupled to M2 receptors by $\beta$ dimers released from $G_{i / o}$ proteins. ${ }^{12,13}$ However, there is no direct evidence of $\mathrm{G}_{\mathrm{i} / \mathrm{o}}$-mediated regulation of $\mathrm{m} I_{\text {CAT }}$ in GI smooth muscle to date. In studies of the $\mathrm{IP}_{3}$ mediated pathway, flash photolysis of "caged" $\mathrm{IP}_{3}$ augmented $\mathrm{m} I_{\text {CAT }}$ in guinea-pig ileal cells suggesting that $\mathrm{IP}_{3}$ receptor-mediated release plays a central role in modulation of $\mathrm{m} I_{\mathrm{CAT}}{ }^{14}$ Intracellular $\mathrm{Ca}^{2+}$ has been shown to facilitate $\mathrm{m} I_{\mathrm{CAT}}$ in certain species. ${ }^{15,16}$ Interestingly, the inhibitory effect of $\mathrm{Ca}^{2+}$-dependent PKC on $\mathrm{m} I_{\mathrm{CAT}}$ suggests that endogenous stimulation of $\mathrm{PKC}$ by ACh might be responsible for desensitization of $\mathrm{m} I_{\mathrm{CAT}}{ }^{17}$

The Rho-kinase (RhoK) pathway is a major signaling cascade that controls GI smooth muscle contraction. Recently there have been many reports about the importance of this pathway in GI muscle. ${ }^{18-21}$ The initiating step in this pathway is the small GTPase, RhoA that is activated by receptors coupled to $G_{12 / 13}$. M3 receptors also couple through $G_{12 / 13}$ and $G_{q} / G_{11}$ can also rapidly activate RhoA. ${ }^{22}$ In the active GTP-bound state, RhoA asso-

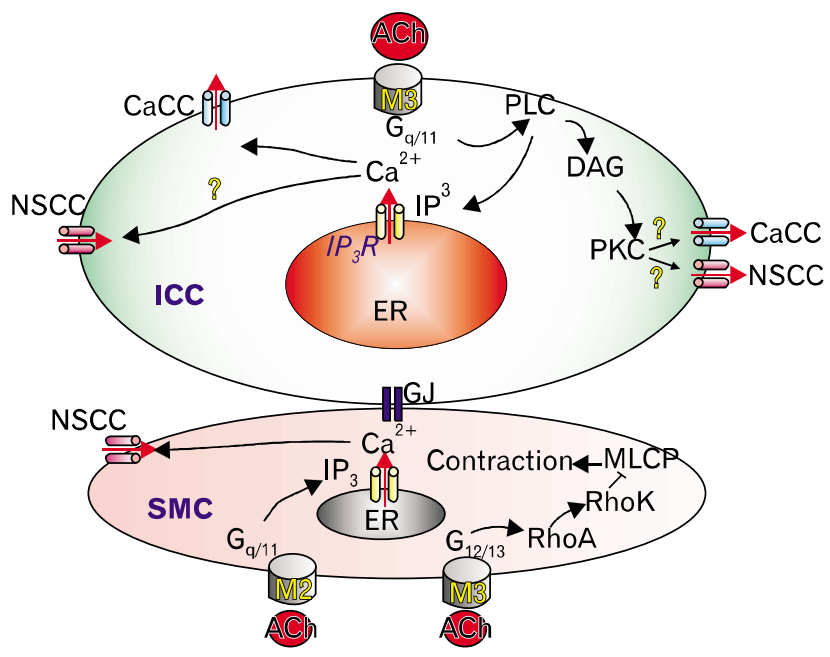

Figure 1. Possible post-junctional mechanisms responsible for cholinergic excitation. Acetylcholine (ACh) is coupled to $G_{q / 11}$ protein and activates conductance(s) through inositol 1,4,5-triphosphate receptor $\left(\mathrm{IP}_{3} \mathrm{R}\right)$ in interstitial cells of Cajal (ICC) and smooth muscle cells (SMC). ACh might also be coupled to $\mathrm{G}_{12 / 13}$ protein and activate Rho-Kinase (RhoK) pathway to induce contraction in SMC. ER, endoplasmic reticulum; PLC, phospholipase C; DAG, diacyl glycerol; PKC, protein kinase $\mathrm{C}$; $\mathrm{CaCC}, \mathrm{Ca}^{2+}$-activated $\mathrm{Cl}^{-}$channels; NSCC, non-selective cation channels; GJ, gap junction; MLCP, myosine light chain phosphatase.

ciates with its main downstream effector, RhoK and inhibits myosin light-chain phosphatase (Fig. 1), thus increasing the phosphorylation state of myosin and the contractile responses to intracellular $\mathrm{Ca}^{2+}\left[\mathrm{Ca}^{2+}\right]_{\mathrm{i}}$. However, it is important to note the non-specificity of RhoK inhibitors. Studies of GI muscle have neglected the fact that RhoK may also be coupled to membrane excitability mechanisms. In addition recent studies have indicated that the RhoA signaling modulates a growing number of ion channels. ${ }^{23-25}$ RhoK has also been suggested to affect $\mathrm{Ca}^{2+}$ influx through inhibition of non-selective cation channels (NSCC). ${ }^{26,27}$ It is worthwhile to note that the pharmacology of native NSCC is complicated and there are no specific blockers for these channels. Therefore, studying the role of NSCC in tissue experiments is still problematic.

NSCC is important conductance in understanding the fundamental excitatory pathway in GI SMC, but evidence to date suggests that cholinergic activation of these channels is unlikely to occur to any great extent in vivo. In $W / W^{v}$ murine fundus which ICCs were ablated, the EJP was abolished suggesting that cholinergic activation of the gut appears to occur primarily through activation of $\mathrm{M} 3$ receptors in ICC. ${ }^{28,29}$ Recently, many 
studies reported that ICC uniquely express the Ano1 (Tmem16a) transcript and protein. ${ }^{30-32}$ Ano1 is a molecular candidate for $\mathrm{Ca}^{2+}$-activated $\mathrm{Cl}^{-}$channels $(\mathrm{CaCC})$ which could be another candidate conductance in response to ACh (Fig. 1). Activation of M3 receptors by $\mathrm{ACh}$ in ICC increases intracellular $\mathrm{Ca}^{2+}$ through the PLC-downstream pathway. Thus, an increase in $\mathrm{Ca}^{2+}$ can activate $\mathrm{Cl}^{-}$conductance. However, this hypothesis has not been carefully studied. Interestingly, mice which express copGFP constitutively only in ICC displayed functional expression of ANO1 in small intestinal smooth muscle. ${ }^{31,32}$ Using isolated ICC cells from these mice, the characterization of activated currents by muscarinic agonists will be important to interpret the ionic conductance responsible for EJP. Another strong approach will be generation of Ano1 knockout (KO) mice. Unfortunately, the conventional Ano1 KO mouse dies within 20 days after birth. It is necessary to generate an inducible Ano1 KO mouse to elucidate the functional role of $\mathrm{CaCC}$ in $\mathrm{ICC}$ in response to EJP.

\section{Peptidergic Excitatory Response}

It has been suggested that high frequency stimulation of electrical field stimulation $(\mathrm{EFS})(>10 \mathrm{~Hz}$ ) releases neuropeptides. NKs and tachykinins are the candidates for excitatory peptides. Substance $\mathrm{P}$ binds to neurokinin 1 (NK1) receptors, neurokinin A (NKA) binds to neurokinin 2 (NK2) receptors and neurokinin $\mathrm{B}$ (NKB) binds to neurokinin 3 (NK3) receptors. ${ }^{33}$ Activation of these receptors induces activation of PLC and produces $\mathrm{IP}_{3}$. Thus, we speculate that the functional role of NKs is not much different from ACh. Activation of these receptors induces depolarization and contraction. The distribution of NK receptors is interesting. The NK1 receptor is mainly expressed in ICC and NK2 receptors are expressed in SMC. ${ }^{34,35}$ Application of NKA and substance $\mathrm{P}$ in canine colonic SMC activates NSCC similar to $\mathrm{m} I_{\text {СAT. }}{ }^{36}$ In tissue experiments, $W / W^{v}$ and $W s / W s$ fundus revealed that substance P-mediated excitation with the marked spontaneous phasic contraction was augmented compared to wild type. These data suggest that the absence of ICC would give the musculature unmasked access to substance $\mathrm{P}$ since fundic ICC are innervated by dominantly inhibitory neurotransmitter (e.g., NO). Although there is no report about the effects of NKs on ICC conductance, it will be worthwhile to characterize the ionic conductance activated by $\mathrm{NKs}$ in comparison with the ionic conductance in SMC. It might be possible to activate $\mathrm{CaCC}$ through the PLC-downstream pathway with an increase in intracellular
$\mathrm{Ca}^{2+}$ by NKs in ICC.

\section{Purinergic Inhibitory Response}

EFS evoked a EJP followed by a fast hyperpolarization (fast IJP) in GI smooth muscle. The phenomenon resulted from activation of $\mathrm{P} 2 \mathrm{Y}$ receptors by purines (mainly ATP or $\beta-N A D) .{ }^{37-41}$ There are eight identified human $\mathrm{P} 2 \mathrm{Y}$ receptors:

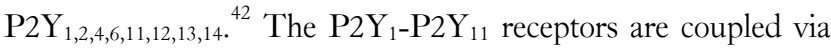
$\mathrm{G}_{\mathrm{q} / 11}$ and $\mathrm{P} 2 \mathrm{Y}_{12}-\mathrm{P} 2 \mathrm{Y}_{14}$ receptors are coupled via $\mathrm{G}_{\mathrm{i} / \mathrm{o}}{ }^{42}$ Recent evidence showed that $\mathrm{P} 2 \mathrm{Y} 1$ receptor has the most prominent role in fast IJP. MRS2500, a specific blocker for the P2Y1 receptor, completely abolished fast IJP. ${ }^{37-40}$ Furthermore, P2ry $1 \mathrm{KO}$ mice showed the absence of fast IJP. ${ }^{39,40} \mathrm{P} 2 \mathrm{Y} 1$ receptors are coupled to $\mathrm{G}_{\mathrm{q} / 11}$ and activate PLC downstream signaling. An increase in $\mathrm{IP}_{3}$ production and in turn, release of intracellular $\mathrm{Ca}^{2+}$ from $\mathrm{IP}_{3}$ $\mathrm{Ca}^{2+}$ store may be the key component. $\mathrm{Ca}^{2+}$-dependent $\mathrm{K}^{+}$conductance(s) is the main candidate to generate hyperpolarization. Apamin, a blocker of small-conductance $\mathrm{Ca}^{2+}$-activated $\mathrm{K}^{+}(\mathrm{SK})$ channels, inhibits partially the fast IJP. ${ }^{41,43,44}$ Thus, activation of SK channels coupled to $\mathrm{P} 2 \mathrm{Y} 1$ receptor could be one of the main

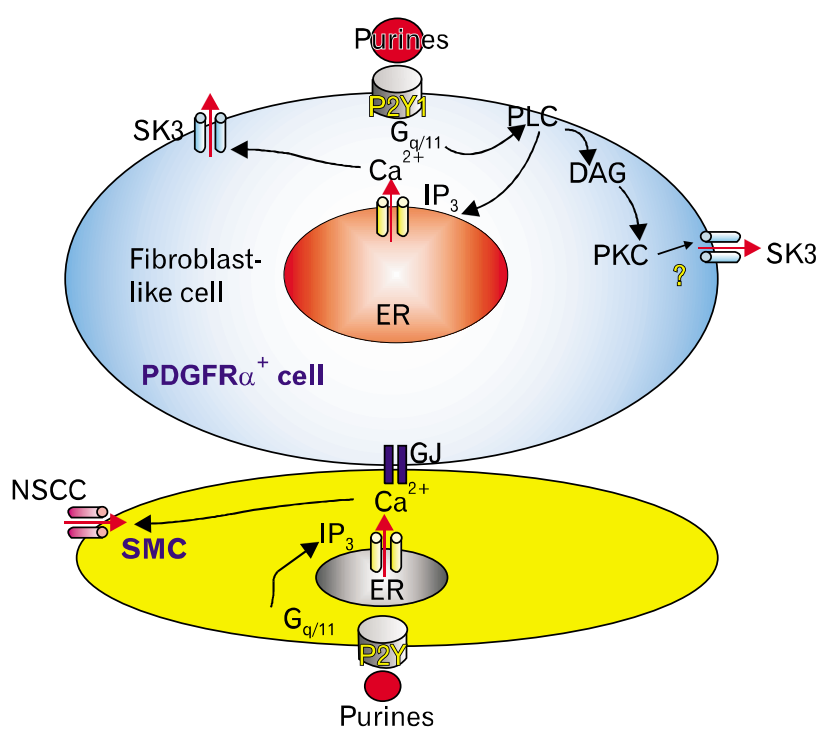

Figure 2. Possible post-junctional mechanisms responsible for purinergic inhibition. Purines (ATP and $\beta$-NAD) are coupled to $G_{q / 11}$ protein and activate conductance(s) through inositol 1,4,5-triphosphate receptor $\left(\mathrm{IP}_{3} \mathrm{R}\right)$ in platelet-derived growth factor receptor $\alpha$-positive cells $\left(\mathrm{PDGFR}^{+}\right.$cell) and smooth muscle cells (SMC). ER, endoplasmic reticulum; PLC, phospholipase C; DAG, diacyl glycerol; $\mathrm{PKC}$, protein kinase $\mathrm{C}$; SK3, small-conductance $\mathrm{Ca}^{2+}$-activated $\mathrm{K}^{+}$ channels type 3; NSCC, non-selective cation channels; GJ, gap junction. 
responses to generate fast IJP. It is important to discuss the specialized cell in response to fast IJP. Previously, the purinergic inhibitory response was regarded to result from the activation of SK channel in SMC. ${ }^{45,46}$ However, recently the fibroblast-like cells were identified as PDGFRa immunoreactive positive cell, confirmed by using transgenic mice which expressed eGFP in nuclei $\left(\mathrm{PDGFR} \alpha^{+}\right.$cell). ${ }^{47-49} \mathrm{PDGFR}^{+}$cell under patch clamp displayed a large outward current which was inhibited by apamin. ${ }^{49}$ The current density of PDGFR $\alpha^{+}$cells is much higher than in $\mathrm{SMC}$. Thus, there is strong possibility that fast IJP responses evoked by purines are mediated through $\mathrm{P} 2 \mathrm{Y} 1$ receptor and SK channels in PDGFR $\alpha^{+}$cells (Fig. 2). This hypothesis still needs to be confirmed with inducible Pdgfr $\alpha \mathrm{KO}$ mice since conventional $P$ dgfr $\alpha \mathrm{KO}$ mice are not viable.

\section{Nitrergic Inhibitory Response}

Enteric nitric oxide synthase (NOS) containing inhibitory neurons releases $\mathrm{NO} .{ }^{50} \mathrm{NO}$ induced slow hyperpolarization (slow IJP) and relaxed GI smooth muscle by neural stimulation. ${ }^{51-55}$ NO activates soluble guanylate cyclase, produces 3',5'-guanosine cyclic monophosphate (cGMP), and activates protein kinase $\mathrm{G}$ (PKG). NOS inhibitors (e.g., L-NNA) and soluble guanylate cyclase inhibitors (e.g., ODQ) abolish slow IJP. ${ }^{56}$ Firstly, slow IJP could be due to activation of $\mathrm{K}^{+}$conductance. Functional presence of stretch-dependent $\mathrm{K}^{+}$(SDK) channels has been reported in colonic myocytes. ${ }^{57,58} \mathrm{SDK}$ channels are activated by NO, a membrane-permeable analogue of cGMP and PKG. L-methionine and its derivatives inhibit SDK channels and decrease the evoked slow IJP. ${ }^{59}$ TREK-1 channel has been found to be a molecular candidate for native SDK channels in murine colonic myocytes. ${ }^{60}$ TREK-1 channel has a similar single channel conductance and regulatory properties including the effects of $\mathrm{NO}$ and membrane permeable analogue of cGMP. Secondly, slow IJP could also be due to inhibition of inward conductance. There are reports that slow IJP, particularly in esophageal smooth muscle, is due to inhibition of $\mathrm{CaCC}$ in tissue experiments. ${ }^{61,62}$ As is known, $\mathrm{CaCC}$ blockers are notorious by non-specificity. The inhibition of $\mathrm{CaCC}$ in $\mathrm{SMC}$ by $\mathrm{NO}$ has not been reported to date. Thus, the candidate of ionic conductance for slow IJP is still controversial. It is important to note that the NO component of IJP (sIJP) was abolished in ICC ablated mice $\left(W / W^{v}\right.$ and $\left.S l / S l^{d}\right)$ and rat $\left(W_{s} / W s\right){ }^{63-65}$ Recently, an ICC-specific deletion of PKG decreased the slow $\mathrm{IJP}^{66}$ (Fig. 3). These data suggest that the slow IJP may be evoked by PKG activation

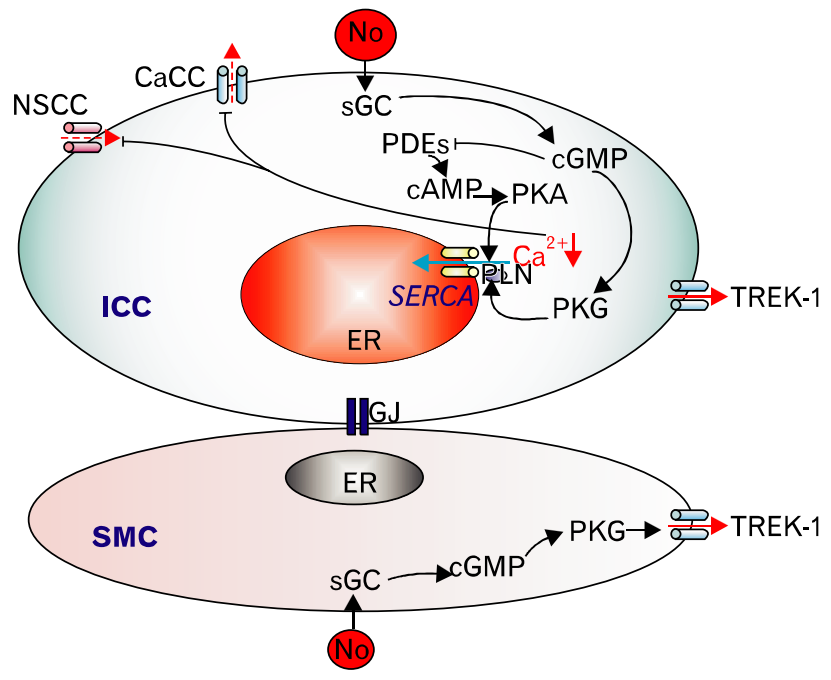

Figure 3. Possible post-junctional mechanisms responsible for nitrergic inhibition. Nitric oxide (NO) directly activates soluble guanylate cyclase (sGC) and activates conductance(s) through various possible mechanisms in interstitial cells of Cajal (ICC) and smooth muscle cells (SMC). ER, endoplasmic reticulum; cGMP, 3',5'-guanosine cyclic monophosphate; PKG, protein kinase G; PDEs, phosphodiesterases; cAMP, 3'5'-adensosine cyclic monophosphate; PKA, protein kinase A. SERCA, sarco/endoplasmic reticulum $\mathrm{Ca}^{2+}$-ATPase; $\mathrm{CaCC}, \mathrm{Ca}^{2+}$. activated $\mathrm{Cl}^{-}$channels; NSCC, non-selective cation channels.

and may not be due to the activation of ion channels in SMC but in ICC. We need to consider that phosphodiesterase $3 \mathrm{a}$ is highly expressed in ICC. ${ }^{6}$ This enzyme is inhibited by cGMP. Inhibition of phosphodiesterase $3 \mathrm{a}$ can increase the concentration of cAMP and activity of protein kinase A (PKA). PKA including $\mathrm{PKG}$ might involve the phosphorylation of phospholamban in sarco/endoplasmic reticulum $\mathrm{Ca}^{2+}$-ATPase (SERCA) in ICC, and in turn $\mathrm{Ca}^{2+}$ influx into the endoplasmic reticulum might be augmented (Fig. 3). In addition to activation of $\mathrm{K}^{+}$conductance by $\mathrm{PKG}$, it is possible to inhibit $\mathrm{Ca}^{2+}$-activated inward conductance in ICC during NO release. Thus, it will be very important to investigate ionic conductance(s) evoked by $\mathrm{NO}$ and its intracellular signaling mechanisms in freshly dispersed ICC.

\section{Peptidergic Inhibitory Response}

VIP and PACAP are known to be enteric inhibitory peptides. $^{67}$ These peptides induce hyperpolarization and relaxation of the GI smooth muscle. ${ }^{68}$ In rat colonic smooth muscle, the VIP antagonist (VIP10-28) blocked the inhibitory response elicited by EFS. ${ }^{69}$ Two VIP receptors, VPAC1 and VPAC2 are activated by both peptides. VPAC2 is predominantly expressed in the GI 
tract. $^{68,70}$ This receptor is coupled to Gs and increases the production of cAMP. VIP activates delayed rectifying $\mathrm{K}^{+}$currents $\left(\mathrm{K}_{\mathrm{DR}}\right)$ via $\mathrm{PKA}$ activation in SMC. ${ }^{71}$ However, $\mathrm{K}_{\mathrm{DR}}$ currents are voltage-dependent and thus have a threshold for activation $(\sim 40$ $\mathrm{mV}$ ). The activation of $\mathrm{K}_{\mathrm{DR}}$ currents cannot undergo further hyperpolarization from the resting membrane potentials. In contrast, PACAP induced-hyperpolarization was inhibited by apamin suggesting that activation of SK channel may be mediated through VPAC1 receptors which are coupled to $G_{q / 11}$. However there is no clear study of ion channels regarding how VIP and PACAP can induce hyperpolarization. Also, no study has shown what types of cells (ICC or PDGFR $\alpha^{+}$cell) are mediated by peptidergic inhibitory responses.

In conclusion, it is not clear what types of receptors, ion channels and cells stimulated by enteric motor neurons are involved in post-junctional responses. Studies with animal models (e.g., $W / W^{v}, W_{s} / W s$ and $S l / S l^{d}$ etc) suggested that specialized cells are involved in post-junctional responses. For instance, ICC are coupled to SMC through gap junction. PDGFR $\alpha^{+}$cells have a similar electrical coupling to SMC. Thus it is possible that neurotransmitters and possibly peptides can bind to the receptors in these specialized cells, generate electrical events and conduct these electrical events to the SMC. Three types of cells (SMC, ICC and PDGFR $\alpha^{+}$cell) can be candidates in response to neurotransmitters and neuropeptides. Many studies in tissue experiments have relied on pharmacology. Many receptor antagonists and some ion channel blockers are non-specific. This non-specificity can be solved by direct investigation of functional expression of ion channels in these cell types. Since there was only a limited approaches to isolate and separate the specialized cells (e.g., ICC and PDGFR $\alpha^{+}$cell), the characterization of ionic conductance(s) in SMCs has been studied extensively. Recent transgenic approaches make it possible to identify ICC and PDGFR $\alpha^{+}$ cells. Characterization of the ion channels in these cells activated by neurotransmitters and neuropeptides will elucidate new concepts of electrophysiology of GI smooth muscle. Finally we have to consider the difference of electrical responses in the human GI smooth muscle. Although many transgenic animals will be generated and developed for the future, studies on ionic conductance activated by transmitters or peptides using human smooth muscle should be emphasized.

\section{References}

1. Koh SD, Ward SM, Sanders KM. Ionic conductances regulating the excitability of colonic smooth muscles. Neurogastroenterol Motil 2012;24:705-718.

2. Sanders KM, Koh SD, Ro S, Ward SM. Regulation of gastrointestinal motility - insights from smooth muscle biology. Nat Rev Gastroenterol Hepatol 2012;9:633-645.

3. Bulbring E. Postjunctional adrenergic mechanisms. Br Med Bull 1979;35:285-293.

4. Unno T, Kwon SC, Okamoto H, et al. Receptor signaling mechanisms underlying muscarinic agonist-evoked contraction in guinea-pig ileal longitudinal smooth muscle. Br J Pharmacol 2003;139: 337-350.

5. Iino S, Nojyo Y. Muscarinic $\mathrm{M}_{2}$ acetylcholine receptor distribution in the guinea-pig gastrointestinal tract. Neuroscience 2006;138: 549-559.

6. Chen H, Redelman D, Ro S, Ordög T, Sanders KM. Selective labeling and isolation of functional classes of interstitial cells of Cajal of human and murine small intestine. Am J Physiol Cell Physiol 2007;292:C497-C507.

7. Berridge MJ, Lipp P, Bootman MD. The versatility and universality of calcium signalling. Nat Rev Mol Cell Biol 2000;1:11-21.

8. Berridge MJ, Lipp P, Bootman MD. Signal transduction. The calcium entry pas de deux. Science 2000;287:1604-1605.

9. Lee YM, Kim BJ, Kim HJ, et al. TRPC5 as a candidate for the nonselective cation channel activated by muscarinic stimulation in murine stomach. Am J Physiol Gastrointest Liver Physiol 2003;284: G604-G616.

10. Zholos AV, Tsytsyura YD, Gordienko DV, vskyy VV, Bolton TB. Phospholipase $\mathrm{C}$, but not InsP3 or DAG, -dependent activation of the muscarinic receptor-operated cation current in guinea-pig ileal smooth muscle cells. Br J Pharmacol 2004;141:23-36.

11. Okamoto H, Unno T, Arima D, et al. Phospholipase C involvement in activation of the muscarinic receptor-operated cationic current in Guinea pig ileal smooth muscle cells. J Pharmacol Sci 2004;95: 203-213.

12. Rebecchi MJ, Pentyala SN. Structure, function, and control of phosphoinositide-specific phospholipase C. Physiol Rev 2000;80:12911335 .

13. Rhee SG. Regulation of phosphoinositide-specific phospholipase C. Annu Rev Biochem 2001;70:281-312.

14. Gordienko DV, Zholos AV. Regulation of muscarinic cationic current in myocytes from guinea-pig ileum by intracellular $\mathrm{Ca}^{2+}$ release: a central role of inositol 1,4,5-trisphosphate receptors. Cell Calcium 2004;36:367-386.

15. Inoue R, Isenberg $G$. Intracellular calcium ions modulate acetylcholine-induced inward current in guinea-pig ileum. J Physiol 1990; 424:73-92.

16. Sims SM. Cholinergic activation of a non-selective cation current in canine gastric smooth muscle is associated with contraction. J Physiol 1992;449:377-398.

17. So I, Kim KW. Nonselective cation channels activated by the stimulation of muscarinic receptors in mammalian gastric smooth muscle. J Smooth Muscle Res 2003;39:231-247.

18. Al-Jarallah A, Khan I, Oriowo MA. Role of $\mathrm{Ca}^{2+}$-sensitization in attenuated carbachol-induced contraction of the colon in a rat model of colitis. Eur J Pharmacol 2008;579:365-373.

19. de Godoy MA, Patel CA, Waldman SA, Katsuki M, Regan RF, 
Rattan S. H-ras inhibits RhoA/ROCK leading to a decrease in the basal tone in the internal anal sphincter. Gastroenterology 2007;132: 1401-1409.

20. Patel CA, Rattan S. Cellular regulation of basal tone in internal anal sphincter smooth muscle by RhoA/ROCK. Am J Physiol Gastrointest Liver Physiol 2007;292:G1747-G1756.

21. Hersch E, Huang J, Grider JR, Murthy KS. $G_{q} / G_{13}$ signaling by ET-1 in smooth muscle: MYPT1 phosphorylation via ETA and CPI-17 dephosphorylation via ETB. Am J Physiol Cell Physiol 2004;287: C1209-C1218.

22. Vogt S, Grosse R, Schultz G, Offermanns S. Receptor-dependent RhoA activation in $G_{12} / G_{13}$-deficient cells: genetic evidence for an involvement of $G_{q} / G_{11}$. J Biol Chem 2003;278:28743-28749.

23. Ghisdal P, Vandenberg G, Morel N. Rho-dependent kinase is involved in agonist-activated calcium entry in rat arteries. J Physiol 2003;551:855-867.

24. Luykenaar KD, Brett SE, Wu BN, Wiehler WB, Welsh DG. Pyrimidine nucleotides suppress KDR currents and depolarize rat cerebral arteries by activating Rho kinase. Am J Physiol Heart Circ Physiol 2004;286:H1088- H1100.

25. Pochynyuk O, Stockand JD, Staruschenko A. Ion channel regulation by Ras, Rho, and Rab small GTPases. Exp Biol Med (Maywood) 2007;232:1258-1265.

26. Villalba N, Stankevicius E, Simonsen U, Prieto D. Rho kinase is involved in $\mathrm{Ca}^{2+}$ entry of rat penile small arteries. Am J Physiol Heart Circ Physiol 2008;294:H1923-H1932.

27. Bayguinov O, Dwyer L, Kim H, Marklew A, Sanders KM, Koh SD. Contribution of Rho-kinase to membrane excitability of murine colonic smooth muscle. Br J Pharmacol 2011;163:638-648.

28. Beckett EA, Bayguinov YR, Sanders KM, Ward SM, Hirst GD. Properties of unitary potentials generated by intramuscular interstitial cells of Cajal in the murine and guinea-pig gastric fundus. J Physiol 2004;559(Pt 1):259-269.

29. Beckett EA, McGeough CA, Sanders KM, Ward SM. Pacing of interstitial cells of Cajal in the murine gastric antrum: neurally mediated and direct stimulation. J Physiol 2003;553(Pt 2):545-559.

30. Sanders KM, Zhu MH, Britton F, Koh SD, Ward SM. Anoctamins and gastrointestinal smooth muscle excitability. Exp Physiol 2012; 97:200-206.

31. Zhu MH, Kim TW, Ro S, Koh SD, Ward SM. A Ca ${ }^{2+}$-activated $\mathrm{Cl}^{-}$conductance in interstitial cells of Cajal linked to slow wave currents and pacemaker activity. J Physiol 2009;587(Pt 20):4905-4918.

32. Zhu MH, Sung IK, Zheng $\mathrm{H}$, et al. Muscarinic activation of $\mathrm{Ca}^{2+}$-activated $\mathrm{Cl}^{-}$current in interstitial cells of Cajal. J Physiol 2011;589(Pt 18):4565-4582.

33. Stahl SM. Substance P and the neurokinins: novel peptide neurotransmitters in psychopharmacology. J Clin Psychiatry 1999;60:7778.

34. Faussone-Pellegrini MS. Relationships between neurokinin receptor-expressing interstitial cells of Cajal and tachykininergic nerves in the gut. J Cell Mol Med 2006;10:20-32.

35. Faussone-Pellegrini MS, Vannucchi MG. Substance P and Neurokinin 1 receptor - expression is affected in the ileum of mice with mutation in the W locus. J Cell Mol Med 2006;10:511-518.

36. Lee HK, Shuttleworth CW, Sanders KM. Tachykinins activate nonselective cation currents in canine colonic myocytes. Am J Physiol
1995;269:C1394-C1401.

37. Gil V, Martínez-Cutillas M, Mañé N, Martín MT, Jiménez M, Gallego D. P2 $Y_{1}$ knockout mice lack purinergic neuromuscular transmission in the antrum and cecum. Neurogastroenterol Motil 2013;25:e170-e182.

38. Gallego D, Gil V, Aleu J, Martinez-Cutillas M, Clavé P, Jimenez M. Pharmacological characterization of purinergic inhibitory neuromuscular transmission in the human colon. Neurogastroenterol Motil 2011;23:792, e338.

39. Gallego D, Gil V, Martinez-Cutillas M, Mañé N, Martín MT, Jiménez M. Purinergic neuromuscular transmission is absent in the colon of $\mathrm{P}_{2} \mathrm{Y}_{1}$ knocked out mice. J Physiol 2012;590(Pt 8): 1943-1956.

40. Hwang SJ, Blair PJ, Durnin L, Mutafova-Yambolieva V, Sanders $\mathrm{KM}$, Ward SM. P2Y1 purinoreceptors are fundamental to inhibitory motor control of murine colonic excitability and transit. J Physiol 2012;590(Pt 8):1957-1972.

41. Mutafova-Yambolieva VN, Hwang SJ, Hao X, et al. Beta-nicotinamide adenine dinucleotide is an inhibitory neurotransmitter in visceral smooth muscle. Proc Natl Acad Sci USA 2007;104:1635916564.

42. Abbracchio MP, Burnstock G, Boeynaems JM, et al. International Union of Pharmacology LVIII: update on the P2Y G protein-coupled nucleotide receptors: from molecular mechanisms and pathophysiology to therapy. Pharmacol Rev 2006;58:281-341.

43. Banks BE, Brown C, Burgess GM, et al. Apamin blocks certain neurotransmitter-induced increases in potassium permeability. Nature 1979;282:415-417.

44. Gallego D, Hernández P, Clavé P, Jiménez M. P2Y1 receptors mediate inhibitory purinergic neuromuscular transmission in the human colon. Am J Physiol Gastrointest Liver Physiol 2006;291:G584G594.

45. Vogalis F, Goyal RK. Activation of small conductance $\mathrm{Ca}^{2+}$-dependent $\mathrm{K}^{+}$channels by purinergic agonists in smooth muscle cells of the mouse ileum. J Physiol 1997;502 (Pt 3):497-508.

46. Koh SD, Dick GM, Sanders KM. Small-conductance $\mathrm{Ca}^{2+}$-dependent $\mathrm{K}^{+}$channels activated by ATP in murine colonic smooth muscle. Am J Physiol 1997;273(6 Pt 1):C2010-C2021.

47. Iino S, Nojyo Y. Immunohistochemical demonstration of c-Kit-negative fibroblast-like cells in murine gastrointestinal musculature. Arch Histol Cytol 2009;72:107-115.

48. Kurahashi M, Nakano Y, Hennig GW, Ward SM, Sanders KM. Platelet-derived growth factor receptor alpha-positive cells in the tunica muscularis of human colon. J Cell Mol Med 2012;16:1397-1404.

49. Kurahashi M, Zheng H, Dwyer L, Ward SM, Don Koh S, Sanders KM. A functional role for the 'fibroblast-like cells' in gastrointestinal smooth muscles. J Physiol 2011;589(Pt 3):697-710.

50. Toda N, Herman AG. Gastrointestinal function regulation by nitrergic efferent nerves. Pharmacol Rev 2005;57:315-338.

51. Suzuki H, Ward SM, Bayguinov YR, Edwards FR, Hirst GD. Involvement of intramuscular interstitial cells in nitrergic inhibition in the mouse gastric antrum. J Physiol 2003;546(Pt 3):751-763.

52. Keef KD, Du C, Ward SM, McGregor B, Sanders KM. Enteric inhibitory neural regulation of human colonic circular muscle: role of nitric oxide. Gastroenterology 1993;105:1009-1016.

53. Plujà L, Fernández E, Jiménez M. Neural modulation of the cyclic 
electrical and mechanical activity in the rat colonic circular muscle: putative role of ATP and NO. Br J Pharmacol 1999;126:883-892.

54. Wang GD, Wang XY, Hu HZ, et al. Inhibitory neuromuscular transmission mediated by the $\mathrm{P} 2 \mathrm{Y} 1$ purinergic receptor in guinea pig small intestine. Am J Physiol Gastrointest Liver Physiol 2007;292: G1483-G1489.

55. Grasa L, Gil V, Gallego D, Martín MT, Jiménez M. P2Y receptors mediate inhibitory neuromuscular transmission in the rat colon. $\mathrm{Br} \mathrm{J}$ Pharmacol 2009; 158:1641-1652.

56. El-Mahmoudy A, Khalifa M, Draid M, et al. NANC inhibitory neuromuscular transmission in the hamster distal colon. Pharmacol Res 2006;54:452-460.

57. Koh SD, Sanders KM. Stretch-dependent potassium channels in murine colonic smooth muscle cells. J Physiol 2001;533(Pt 1): 155-163.

58. Sanders KM, Koh SD. Two-pore-domain potassium channels in smooth muscles: new components of myogenic regulation. J Physiol 2006;570(Pt 1):37-43.

59. Park KJ, Baker SA, Cho SY, Sanders KM, Koh SD. Sulfur-containing amino acids block stretch-dependent $\mathrm{K}^{+}$channels and nitrergic responses in the murine colon. Br J Pharmacol 2005;144:1126-1137.

60. Koh SD, Monaghan K, Sergeant GP, et al. TREK-1 regulation by nitric oxide and cGMP-dependent protein kinase. An essential role in smooth muscle inhibitory neurotransmission. J Biol Chem 2001; 276:44338-44346.

61. Zhang Y, Bissing JW, Xu L, et al. Nitric oxide synthase inhibitors decrease coronary sinus-free radical concentration and ameliorate myocardial stunning in an ischemia-reperfusion model. J Am Coll Cardiol 2001;38:546-554.

62. Zhang Y, Paterson WG. Role of $\mathrm{Ca}^{2+}$-activated $\mathrm{Cl}^{-}$channels and MLCK in slow IJP in opossum esophageal smooth muscle. Am J
Physiol Gastrointest Liver Physiol 2002;283:G104-G114.

63. Ward SM. Interstitial cells of Cajal in enteric neurotransmission. Gut 2000;47(suppl 4):iv40-iv3; discussion iv52.

64. Ward SM, Beckett EA, Wang X, Baker F, Khoyi M, Sanders KM. Interstitial cells of Cajal mediate cholinergic neurotransmission from enteric motor neurons. J Neurosci 2000;20:1393-1403.

65. Ward SM, Gershon MD, Keef K, Bayguinov YR, Nelson C, Sanders KM. Interstitial cells of Cajal and electrical activity in ganglionic and aganglionic colons of mice. Am J Physiol Gastrointest Liver Physiol 2002;283:G445-G456.

66. Klein S, Seidler B, Kettenberger A, et al. Interstitial cells of Cajal integrate excitatory and inhibitory neurotransmission with intestinal slow-wave activity. Nat Commun 2013;4:1630.

67. Matsuda NM, Miller SM. Non-adrenergic non-cholinergic inhibition of gastrointestinal smooth muscle and its intracellular mechanism(s). Fundam Clin Pharmacol 2010;24:261-268.

68. Sanders KM. G protein-coupled receptors in gastrointestinal physiology. IV. Neural regulation of gastrointestinal smooth muscle. Am J Physiol 1998;275(1 Pt 1):G1-G7.

69. Kishi M, Takeuchi T, Suthamnatpong N, et al. VIP- and PACAPmediated nonadrenergic, noncholinergic inhibition in longitudinal muscle of rat distal colon: involvement of activation of charybdotoxinand apamin-sensitive $\mathrm{K}^{+}$channels. Br J Pharmacol 1996;119:623630.

70. Alexander SP, Mathie A, Peters JA. Guide to Receptors and Channels (GRAC), 3rd edition. Br J Pharmacol 2008;153(suppl 2):S1-S209.

71. Shuttleworth CW, Koh SD, Bayginov O, Sanders KM. Activation of delayed rectifier potassium channels in canine proximal colon by vasoactive intestinal peptide. J Physiol 1996;493 (Pt 3):651-663. 